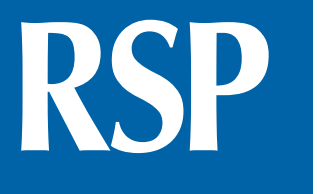

http://www.rsp.fsp.usp.br/
Revista de Saúde Pública

\title{
Oropharyngeal colostrum immunotherapy and nutrition in preterm newborns: meta-analysis
}

\author{
Michelle de Santana Xavier Ramos ${ }^{1,11}$ (iD, Camilla da Cruz Martins' iD, Elivan Silva Souza"II iD, \\ Graciete Oliveira Vieira' iD, Isaac Suzart Gomes-Filho' iD, Ana Claudia Morais Godoy \\ Figueiredo $^{\mathrm{IV}}$ iD, Maurício Gomes Pereira ${ }^{\mathrm{V}}$ (D), Simone Seixas da Cruz ${ }^{1,1}$ iD \\ ' Universidade Estadual de Feira de Santana. Departamento de Saúde. Feira de Santana, BA, Brasil \\ " Universidade Federal do Recôncavo da Bahia. Centro de Ciências da Saúde. Santo Antônio de Jesus, BA, Brasil \\ III Universidade de Brasília. Faculdade de Ciências da Saúde. Brasília, DF, Brasil \\ iv Secretaria de Estado de Saúde do Distrito Federal. Brasilia, DF, Brasil \\ $\checkmark$ Universidade de Brasília. Escola de Medicina. Brasília, DF, Brasil.
}

\section{Correspondence:}

Michelle de Santana Xavier Ramos Av. Transnordestina, $\mathrm{s} / \mathrm{n}$ -

Novo Horizonte

44036-900 Feira de Santana,

BA, Brasil

e-mail: michellesxavier@gmail.com

Received: Aug 14, 2020

Approved: Dec 12, 2020

How to cite: Xavier Ramos MS, Martins CC, Souza ES, Vieira GO, Gomes-Filho IS, Figueiredo ACMG, et al. Oropharyngeal colostrum immunotherapy and nutrition in preterm newborns: meta-analysis. Rev Saude Publica. 2021;55:59. https://doi.org/10.11606/s15188787.2021055003051

Copyright: This is an open-access article distributed under the terms of the Creative Commons Attribution License, which permits unrestricted use, distribution, and reproduction in any medium, provided that the original author and source are credited.

\section{ABSTRACT}

OBJECTIVE: To investigated the effect of oropharyngeal colostrum immunotherapy in reducing the time required for very low birth weight preterm newborns (VLBW-PTNB: $<1,500 \mathrm{~g}$ and $<37$ weeks) to achieve full enteral nutrition.

METHODS: Literature search was conducted using four databases, including gray literature, with additional manual search of the references of selected articles. Eligibility criteria consisted of randomized clinical trials, without restriction regarding the date or language of the publication. Two independent reviewers performed the article selection and data extraction. The random-effects meta-analysis used a non-standard technique to assess the mean difference in days to achieve full enteral nutrition, carried out by the Stata 15 statistic program.

RESULTS: The systematic review comprised 10 studies, and five were selected for meta-analysis, with a population of 764 VLBW-PTNB and gestational age of birth between 25 and 32 weeks. The studies were conducted between 2011 and 2018 in North America, Asia and Africa, with only one conducted in South America. Altogether, they reported the number of days it took 708 VLBW-PTNB to achieve full enteral nutrition, with newborns treated with immunotherapy showing a shorter time in only three studies. Meta-analysis showed a mean difference of -4.26 days, (95\% CI -7.44; $-1.08 \mathrm{~d})$, with high heterogeneity $\left(\mathrm{I}^{2}=83.1 \%\right)$.

CONCLUSION: The use of oropharyngeal colostrum immunotherapy can reduce the time for VLBW-PTNB to achieve full nutrition when compared to those who used a placebo or received routine care.

DESCRIPTORS: Infant, Very Low Birth Weight. Infant, Premature. Immunotherapy. Colostrum. Systematic Review. 


\section{INTRODUCTION}

Nutrition is essential for the newborn's proper growth and development, especially for very low birth weight preterm newborns (VLBW-PTNB) ${ }^{1}$. The diet for this age group poses a nutritional emergency and great challenge since it must supply some nutrients equivalent to those they would possibly be receiving via the intrauterine route ${ }^{2}$.

Dietary nutrients are also essential for the maturation and development of gastrointestinal function and the installation of a healthy microbiota. Colostrum is rich in immunomodulatory bio-factors, stimulates the cells of the lymphoid tissues, and can favor the maturation of the immune system and the gastrointestinal tract ${ }^{3}$.

Oropharyngeal colostrum immunotherapy is a strategy than can provide antimicrobial and anti-inflammatory protective factors, a true immunological and trophic support ${ }^{4}$, condition needed to reduce the time between the use of parenteral (tube) feeding and full enteral nutrition (intake of 100 to $150 \mathrm{~mL} \cdot \mathrm{kg}^{1}$.day $\left.{ }^{1}\right)^{5}$. Such strategy would offer the VLBW-PTNB the nutrients required for their physical and neurological development ${ }^{6}$.

Although scientific evidence of the positive effect of colostrum on neonatal clinical outcomes $^{3,4,7,8}$ is available in the literature, no study has investigated colostrum immunotherapy associated with full nutrition as a primary outcome. Three randomized controlled clinical trials conducted with VLBW-PTNB have reported that they achieved full nutrition quicker in the colostrum treatment group compared to the control group ${ }^{6,8,9}$. However, other works did not mention the same association ${ }^{10-12}$.

Likewise, the meta-analyses that investigated the effect of oropharyngeal colostrum immunotherapy on morbimortality prevention ${ }^{13-17}$ did not assess the time it took preterm newborns to achieve full enteral nutrition as a primary outcome of interest or did not research this outcome ${ }^{16}$.

Given the need for quality scientific evidence and the limited number of studies regarding the association in question, the current meta-analysis systematically investigated the effect of oropharyngeal colostrum immunotherapy in reducing the time VLBW-PTNBs take to achieve full enteral nutrition. This outcome can contribute to the newborns' proper growth, development, shorter stay in intensive care, and to reduce neonatal morbimortality.

\section{METHODS}

This meta-analysis used the PRISMA standard and included the following steps: registration and protocol; study eligibility criteria; database search; definition of search strategies; data selection, extraction and analysis; and qualitative assessment of the studies.

\section{Registration and Protocol}

We searched for existing systematic reviews on the topic, with no record found. A review protocol was established before its completion and recorded in PROSPERO under number CRD42019126088. The protocol had no significant deviations during the research.

\section{Study Eligibility Criteria}

Eligibility criteria consisted of randomized clinical trials evaluating the effect of oropharyngeal colostrum immunotherapy over the time it took VLBW-PTNBs (gestational age up to 37 weeks and weight below 1,500 g) to achieve full enteral nutrition. We applied no restriction concerning date or language of publication. Non-randomized clinical trials, cohort studies, and narrative and systematic literature reviews were excluded. 


\section{Database Search}

We conducted the literature search until July 31, 2020, in the following electronic databases: Medline/PubMed,Lilacs/Bireme/BVS, Cochrane Central, and Web of Science. Gray literature comprised: CAPES/MEC Portal thesis database, ProQuest Dissertations \& Theses Databases, Clinical Trials study protocols, study protocols from the Brazilian Registry of Clinical Trials and contact with study authors with unpublished results. The references of the articles selected for the systematic review were also searched.

\section{Search Strategies}

We used MeSH descriptors and their synonyms for searching Medline and Cochrane Central, and DeCS descriptors for the Lilacs/Bireme database. The terms in both languages (English and Spanish) were combined using and to ensure a good return of information in Lilacs and Bireme/BVS. To increase search sensitivity in the Medline database, our search strategy included the so-called "entry terms" or Boolean operators within the definition of the MeSH term. Table 1 presents the search strategies used for each database.

\section{Study Selection}

Two independent reviewers (MSXR and CCM) selected the studies by reading the titles and abstracts. Then, the same two researchers independently read the full text of the individually selected papers. Works that met the eligibility criteria were included in the systematic review. Any disagreement between the researchers on the inclusion or exclusion of a paper was settled by consensus (MSXR, CCM).

\section{Data Extraction}

Two independent researchers (MSXR and CCM) extracted the data and later adjudicated them by consensus (Table 2). The data were entered in an Excel spreadsheet containing the following fields: type of publication, author, year of publication, title, objective, analysis method, results, conclusions, name and rating (Qualis) of the journal, research year, duration of follow-up, research funding, country of study, continent of study, inclusion and exclusion criteria, sample size, mean age of participants, mean age standard deviation, description of intervention and control, duration of oropharyngeal colostrum immunotherapy, time needed to achieve minimum enteral nutrition and full enteral nutrition, confounding variables and conflict of interest.

\section{Study Quality Assessment}

To assess the quality of the selected studies, we used the Cochrane risk-of-bias tool for randomized trials $(\operatorname{RoB} 2)^{18}$.

Table 1. Search strategies with keywords and Boolean operators used in different electronic databases.

\begin{tabular}{lccc}
\hline Database & Strategy & $\mathbf{n}$ & Date \\
\hline Cochrane & $\begin{array}{c}\text { colostrum in Title Abstract Keyword AND Infant, Very Low } \\
\text { Birth Weight in Title Abstract Keyword - (Word variations } \\
\text { have been searched) }\end{array}$ & 38 & 20Jul2020 \\
Lilacs & (tw:(infant, very low birth weight) AND (tw:(colostrum)) & 68 & 20Jul2020 \\
Clinical trials & COLOSTRUM | Interventional Studies | & 37 & 20Jul2020 \\
Pubmed & (infant, low birth weight) AND colostrum & 87 & 20Jul2020 \\
Web of Science & (colostrum) AND TÓPICO: (Infant, very low birth weight) & 66 & 20Jul2020 \\
Google Acadêmico & Imunoterapia orofaríngea de colostro & 36 & 20Jul2020 \\
Portal CAPES/MEC & colostrum AND infant, low birth weight & 24 & 20Jul2020 \\
Proquest & colostrum AND Infant, very low birth weight & 40 & 20Jul2020 \\
Rebec & COLOSTRUM & 2 & 20Jul2020 \\
\hline
\end{tabular}

Source: Original of this manuscript. 
Table 2. General characteristics of the studies.

\begin{tabular}{|c|c|c|c|c|c|c|}
\hline $\begin{array}{l}\text { Authors/Year/ } \\
\text { Location }\end{array}$ & $\begin{array}{l}\text { Type of study / } \\
\text { Funding source* }\end{array}$ & $\begin{array}{l}\text { Sample size / } \\
\mathrm{n} / \text { group }\end{array}$ & $\begin{array}{l}\text { Oropharyngeal colostrum } \\
\text { immunotherapy protocol }\end{array}$ & Control group & $\begin{array}{l}\text { Methodological } \\
\text { quality of } \\
\text { studies (Rob 2) }\end{array}$ & $\begin{array}{l}\text { Time to achieve } \\
\text { full enteral } \\
\text { nutrition (days) }\end{array}$ \\
\hline $\begin{array}{l}\text { Lee et al. }{ }^{10}(2015) \\
\text { Seoul, Korea }\end{array}$ & $\begin{array}{l}\text { Randomized } \\
\text { controlled } \\
\text { clinical trial } \\
\text { * Seoul National } \\
\text { University } \\
\text { Medical School }\end{array}$ & $\begin{array}{c}48 \\
\text { Colostrum group } \\
(n=24) \\
\text { Placebo group } \\
(n=24) \\
p=0.86\end{array}$ & $\begin{array}{l}0.2 \mathrm{~mL} \text { of maternal colostrum } \\
\text { was administered via } \\
\text { oropharynx, } 0.1 \mathrm{~mL} \text { into the } \\
\text { right and left oral mucosa } \\
\text { every } 3 \text { hours after } 48 \text { to } 96 \\
\text { hours of life, for } 72 \text { hours, } \\
\text { regardless of the child's } \\
\text { enteral feeding. }\end{array}$ & $\begin{array}{l}0.2 \mathrm{~mL} \text { of sterile water } \\
\text { was administered, } \\
\text { according to the } \\
\text { oropharyngeal } \\
\text { colostrum } \\
\text { immunotherapy } \\
\text { protocol. }\end{array}$ & Low risk & $\begin{array}{l}\text { Colostrum group: } \\
\quad 20(13-27) \\
\text { Placebo group: } \\
17(14.3-25.8)\end{array}$ \\
\hline $\begin{array}{l}\text { Rodriguez et al. }{ }^{8} \\
\text { (2011) } \\
\text { Midwest, EUA }\end{array}$ & $\begin{array}{l}\text { Randomized } \\
\text { controlled } \\
\text { clinical trial } \\
\text { * Not informed }\end{array}$ & 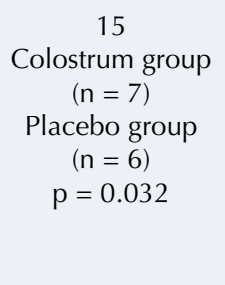 & $\begin{array}{l}0.2 \mathrm{~mL} \text { of maternal colostrum } \\
\text { was administered via } \\
\text { oropharynx, } 0.1 \mathrm{~mL} \text { into the } \\
\text { right and left oral mucosa } \\
\text { before } 48 \mathrm{~h} \text { of life every } 2 \mathrm{~h} \\
\text { for } 48 \mathrm{~h} \text {, enteral feeding was } \\
\text { started after the protocol was } \\
\text { completed. }\end{array}$ & $\begin{array}{l}0.2 \mathrm{~mL} \text { of sterile water } \\
\text { was administered, } \\
\text { according to the } \\
\text { oropharyngeal } \\
\text { colostrum } \\
\text { immunotherapy } \\
\text { protocol. }\end{array}$ & Some concern & $\begin{array}{l}\text { Colostrum group: } \\
14.29 \pm 5.74 \\
\text { Placebo group: } \\
24.17 \pm 8.66\end{array}$ \\
\hline $\begin{array}{l}\text { Sohn et al. }{ }^{7} \text { (2015) } \\
\text { California, USA }\end{array}$ & $\begin{array}{l}\text { Randomized } \\
\text { controlled } \\
\text { clinical trial } \\
\text { * Not informed }\end{array}$ & $\begin{array}{c}12 \\
\text { Colostrum group } \\
(n=6) \\
\text { Control group } \\
(n=6) \\
p=\text { not } \\
\text { statistically } \\
\text { different }\end{array}$ & $\begin{array}{c}0.2 \mathrm{~mL} \text { of maternal colostrum } \\
\text { was administered into the } \\
\text { oral cavity }(0.1 \mathrm{~mL} \text { on each } \\
\text { side of the oral cavity) } \\
\text { every } 2 \text { hours for } 46 \text { hours, } \\
\text { regardless of whether the } \\
\text { child was receiving trophic } \\
\text { food. }\end{array}$ & $\begin{array}{l}\text { Control group } \\
\text { received routine care. }\end{array}$ & High risk & $\begin{array}{l}\text { Colostrum group: } \\
17(14-41) \\
\text { Control group: } \\
13(9-24)\end{array}$ \\
\hline $\begin{array}{l}\text { Glass et al. }{ }^{11} \text {, (2017) } \\
\text { Pennsylvania, USA }\end{array}$ & $\begin{array}{l}\text { Randomized } \\
\text { controlled } \\
\text { clinical trial } \\
\text { * Not informed }\end{array}$ & $\begin{array}{c}30 \\
\text { Colostrum group } \\
(\mathrm{n}=17) \\
\text { Sterile water } \\
\text { group } \\
(\mathrm{n}=13) \\
\mathrm{p}=\text { not } \\
\text { statistically } \\
\text { different }\end{array}$ & $\begin{array}{l}0.2 \mathrm{~mL} \text { of maternal colostrum } \\
\text { was administered to the oral } \\
\text { mucosa with a swab every } 3 \\
\text { hours for } 2 \text { to } 7 \text { days. }\end{array}$ & $\begin{array}{l}0.2 \mathrm{~mL} \text { of sterile water } \\
\text { was administered, } \\
\text { according to the } \\
\text { oropharyngeal } \\
\text { colostrum } \\
\text { immunotherapy } \\
\text { protocol. }\end{array}$ & High risk & $\begin{array}{l}\text { Colostrum group: } \\
24.2 \pm 7.9 \\
\text { Sterile water } \\
\text { group: } 24.9 \pm 9.4\end{array}$ \\
\hline $\begin{array}{l}\text { Romano-Keeler et al. }{ }^{21} \text {, } \\
\text { (2016) } \\
\text { Nashville, Tennessee, } \\
\text { USA }\end{array}$ & $\begin{array}{l}\text { Randomized } \\
\text { controlled } \\
\text { clinical trial } \\
\text { * Thrasher } \\
\text { Research Fund, } \\
\text { USA }\end{array}$ & $\begin{array}{l}99 \\
\text { Colostrum group } \\
(n=48) \\
\text { Non colostrum } \\
\text { group }(n=51) \\
p=0.39\end{array}$ & $\begin{array}{l}0.2 \mathrm{~mL} \text { of maternal colostrum } \\
\text { was administered, started in } \\
\text { the first } 48 \text { hours of life, } 0.1 \\
\mathrm{~mL} \text { on each side of the oral } \\
\text { mucosa every } 6 \text { hours for } 5 \\
\text { days. }\end{array}$ & $\begin{array}{l}\text { Control group } \\
\text { received routine care. }\end{array}$ & High risk & $\begin{array}{l}\text { Colostrum group: } \\
11 \text { (8-15) } \\
\text { Non colostrum } \\
\text { group: } \\
11(9-19)\end{array}$ \\
\hline $\begin{array}{l}\text { Zhang et al. }{ }^{6},(2017) \\
\text { Shanghai, China }\end{array}$ & $\begin{array}{l}\text { Randomized } \\
\text { controlled } \\
\text { clinical trial } \\
\text { * Not informed }\end{array}$ & $\begin{array}{c}55 \\
\text { Colostrum group } \\
(n=27) \\
\text { Control group } \\
(n=28) \\
p=0.09\end{array}$ & $\begin{array}{l}0.2 \mathrm{~mL} \text { of maternal colostrum } \\
\text { was administered, } 0.1 \mathrm{~mL} \text { on } \\
\text { each side of the oral mucosa } \\
\text { with a constant speed of } \\
\text { at least } 20 \text { seconds over } 4 \\
\text { hours, for seven days. }\end{array}$ & $\begin{array}{l}0.2 \mathrm{~mL} \text { of saline } \\
\text { solution was } \\
\text { administered } \\
\text { according to the } \\
\text { oropharyngeal } \\
\text { administration } \\
\text { protocol. }\end{array}$ & Some concern & $\begin{array}{l}\text { Colostrum group: } \\
24.71 \pm 11.23 \\
\\
\text { Control group: } \\
32.72 \pm 20.11\end{array}$ \\
\hline $\begin{array}{l}\text { Abd-Elgawad et al. }{ }^{9} \text {, } \\
(2019) \\
\text { Egypt }\end{array}$ & $\begin{array}{l}\text { Randomized } \\
\text { controlled } \\
\text { clinical trial } \\
\text { * Not informed }\end{array}$ & $\begin{array}{l}200 \\
\text { Colostrum group } \\
\begin{array}{l}(n=100) \\
\text { Gavage group }(n \\
=100) \\
p<0.01\end{array}\end{array}$ & $\begin{array}{l}0.2 \mathrm{~mL} \text { of maternal colostrum } \\
\text { was administered to the } \\
\text { oral mucosa, involving the } \\
\text { oropharynx, tongue, and } \\
\text { cheeks every } 2 \text { or } 4 \text { hours, } \\
\text { during the pre-feeding } \\
\text { period. When infants met } \\
\text { the criteria for starting } \\
\text { enteral feeding, } 0.2 \mathrm{~mL} \\
\text { of the mother's colostrum } \\
\text { was administered to the } \\
\text { oropharynx, tongue, and } \\
\text { cheeks } 5 \text { minutes before } \\
\text { gavage until Rn reached } \\
\text { complete enteral feeding. }\end{array}$ & $\begin{array}{l}\text { Nothing was } \\
\text { administered during } \\
\text { the pre-feeding period } \\
\text { in the regular gavage } \\
\text { group (control). The } \\
\text { mother's colostrum } \\
\text { or breast milk was } \\
\text { administered via tube } \\
\text { when the premature } \\
\text { infants adjusted to the } \\
\text { criteria to start enteral } \\
\text { feeding. }\end{array}$ & Some concern & $\begin{array}{c}\text { Colostrum group: } \\
11.10 \pm 2.1 \\
\text { Gavage group: } \\
15.57 \pm 1.9\end{array}$ \\
\hline
\end{tabular}


Table 2. General characteristics of the studies. Continuation

\begin{tabular}{|c|c|c|c|c|c|c|}
\hline $\begin{array}{l}\text { Sharma et al. }{ }^{12} \text {, } \\
(2020) \\
\text { India }\end{array}$ & $\begin{array}{l}\text { Randomized } \\
\text { controlled } \\
\text { clinical trial } \\
* \text { Not informed }\end{array}$ & $\begin{array}{c}117 \\
\text { Colostrum group } \\
(n=59) \\
\text { Control group } \\
(n=58) \\
p=0.61\end{array}$ & $\begin{array}{l}\text { Oropharyngeal } \\
\text { administration of } 0.2 \mathrm{~mL} \text { of } \\
\text { maternal colostrum to the } \\
\text { oral mucosa, } 0.1 \mathrm{~mL} \text { directed } \\
\text { to the oropharynx on both } \\
\text { sides. Started after } 24 \text { hours } \\
\text { of life every } 2 \text { hours for } \\
72 \text { hours, regardless of the } \\
\text { infant's enteric feeding status. }\end{array}$ & $\begin{array}{l}\text { Control group } \\
\text { newborns received } \\
\text { routine care. }\end{array}$ & High & $\begin{array}{c}\text { Colostrum group: } \\
\qquad \begin{array}{c}10.1 \pm 5.7 \\
\text { Control group: } \\
10.7 \pm 4.3\end{array}\end{array}$ \\
\hline $\begin{array}{l}\text { Shiney Easo et al. }{ }^{23} \\
(2018) \\
\text { Kuwait }\end{array}$ & $\begin{array}{l}\text { Randomized } \\
\text { controlled } \\
\text { clinical trial } \\
* \text { Not informed }\end{array}$ & $\begin{array}{c}43 \\
\text { Colostrum group } \\
(n=21) \\
\text { Control group } \\
(n=22) \\
p=0.888\end{array}$ & $\begin{array}{l}0.1 \mathrm{~mL} \text { of colostrum or fresh } \\
\text { or chilled breast milk was } \\
\text { administered slowly to the } \\
\text { posterior end of the oral } \\
\text { cavity, drop by drop over } 30 \\
\text { s. Procedure was repeated } \\
\text { on the opposite side. Therapy } \\
\text { was started right after birth, } \\
\text { every } 4 \text { hours, and continued } \\
\text { until reaching complete } \\
\text { enteral feeding. }\end{array}$ & $\begin{array}{l}\text { Control group } \\
\text { received } 0.2 \mathrm{~mL} \text { of } \\
\text { sterile water applied } \\
\text { in the same way and } \\
\text { frequency as the } \\
\text { intervention group. } \\
\text { Started in the first } 6 \\
\text { hours of life. }\end{array}$ & Some concern & $\begin{array}{l}\text { Colostrum group: } \\
16(10-25.5) \\
\text { Control group: } \\
16(11-22)\end{array}$ \\
\hline $\begin{array}{l}\text { Ferreira et al. }{ }^{22} \text { (2019) } \\
\text { Brazil }\end{array}$ & $\begin{array}{l}\text { Randomized } \\
\text { controlled } \\
\text { clinical trial } \\
\text { * The Minas } \\
\text { Gerais Research } \\
\text { Support } \\
\text { Foundation } \\
\text { Brasil }\end{array}$ & $\begin{array}{c}145 \\
\text { Feeding achieved } \\
100 \mathrm{~mL} / \mathrm{kg} / \text { day } \\
\text { Colostrum group } \\
(\mathrm{n}=47) \\
\text { Placebo group } \\
(\mathrm{n}=66) \\
\mathrm{p}=0.45 \\
\text { Feeding achieved } \\
150 \text { mL/kg/day } \\
\text { Colostrum group } \\
(\mathrm{n}=47) \\
\text { Placebo group ( } \mathrm{n} \\
=66) \\
\mathrm{p}=0.44\end{array}$ & $\begin{array}{c}0.2 \mathrm{~mL} \text { of maternal colostrum } \\
\text { was administered in the first } \\
48 \text { or } 72 \text { hours of life every } \\
2 \text { hours for } 48 \text { hours, } 0.1 \mathrm{~mL} \\
\text { to the right oral mucosa, and } \\
0.1 \mathrm{~mL} \text { to the left. }\end{array}$ & $\begin{array}{l}0.2 \mathrm{~mL} \text { of sterile water } \\
\text { was administered, } \\
\text { according to the } \\
\text { oropharyngeal } \\
\text { colostrum } \\
\text { immunotherapy } \\
\text { protocol. }\end{array}$ & Some concern & $\begin{array}{c}\text { Feeding achieved } \\
\text { 100mL. } \mathrm{kg}^{-1} \text {.day } \\
\text { Colostrum group: } \\
16(13-22) \\
\text { Placebo group: } \\
18 \text { (15-20) } \\
\text { Feeding achieved } \\
\text { 150mL. kg-1.day } \\
\text { Colostrum group: } \\
20 \text { (18-26) } \\
\text { Placebo group: } \\
24 \text { (18-25) }\end{array}$ \\
\hline
\end{tabular}

Note: The time to reach full enteral nutrition (days) was presented as median (interquartile range) in studies $10,7,21,23$ and 22 and on mean \pm standard deviation in studies $8,11,6,9$ and 12 . Source: Original of this manuscript.

\section{Data Analysis}

After the pre-selection (by two reviewers) of the studies as per the inclusion criteria using the StArt (State of the Art through Systematic Review) tool, with a third reviewer consulted to achieve consensus, the researchers prepared a summary of the qualitative data of the included studies comprising the characteristics of the investigations. Statistical heterogeneity was assessed using $\mathrm{I}^{2}$; depending on the magnitude of this indicator, we performed a meta-analysis ${ }^{19}$ and assessed the magnitude of the inconsistency. The random-effects meta-analysis used nonstandard technique to assess the mean difference in days to achieve full enteral nutrition ${ }^{20}$. Weighted mean difference was used to combine the effect size estimates of the study. The estimate of the combined effect in this method represents a weighted average of all studies that included group comparisons.

For group comparisons in the analysis, each individual result is assigned a weight inversely proportional to the variance; thus larger trials are assigned more weight, and smaller trials, less weight. The analysis was conducted using Stata 15 statistic program.

\section{RESULTS}

\section{Selected Studies}

The literature search identified 398 articles, with three manually added after examining the references of the selected papers, totaling 401 studies for reading titles and abstracts. 
This first screening removed 224 duplicates and excluded 146 studies that did not meet the topic of interest, leaving 31 papers to be read in full. After this second reading, we excluded 21 studies: 16 for not describing the outcome of interest, and five for not being a randomized clinical trial. Only 10 studies met the eligibility criteria for this systematic review (Figure 1). The publication period for the included investigations was until July 2020.

\section{General Characteristics and Quality of the Studies}

All the studies included in this review were randomized clinical trials, comprising a study population of 764 VLBW-PTNB, with gestational age between 25 and 32 weeks, weighing below 1,500 g. The surveys were conducted from 2011 to 2018, with most papers conducted in North American, Asian, and African countries, and only one South American country.

All the included studies aimed to evaluate the efficacy of oropharyngeal colostrum immunotherapy on outcomes related to some health condition of newborns by comparing the administration of oropharyngeal colostrum versus the use of placebo (sterile water or saline solution) or routine care. Nine studies were published ${ }^{6-12,21,22}$ and one was described in an unpublished report provided by its author ${ }^{23}$.

The therapeutic clinical protocol in the analyzed studies consisted in administering $0.2 \mathrm{~mL}$ of colostrum in the oropharynx of newborns, $0.1 \mathrm{~mL}$ in the right oral mucosa and $0.1 \mathrm{~mL}$ in the left mucosa with sterile tuberculin syringes, except for two studies: one, which used the

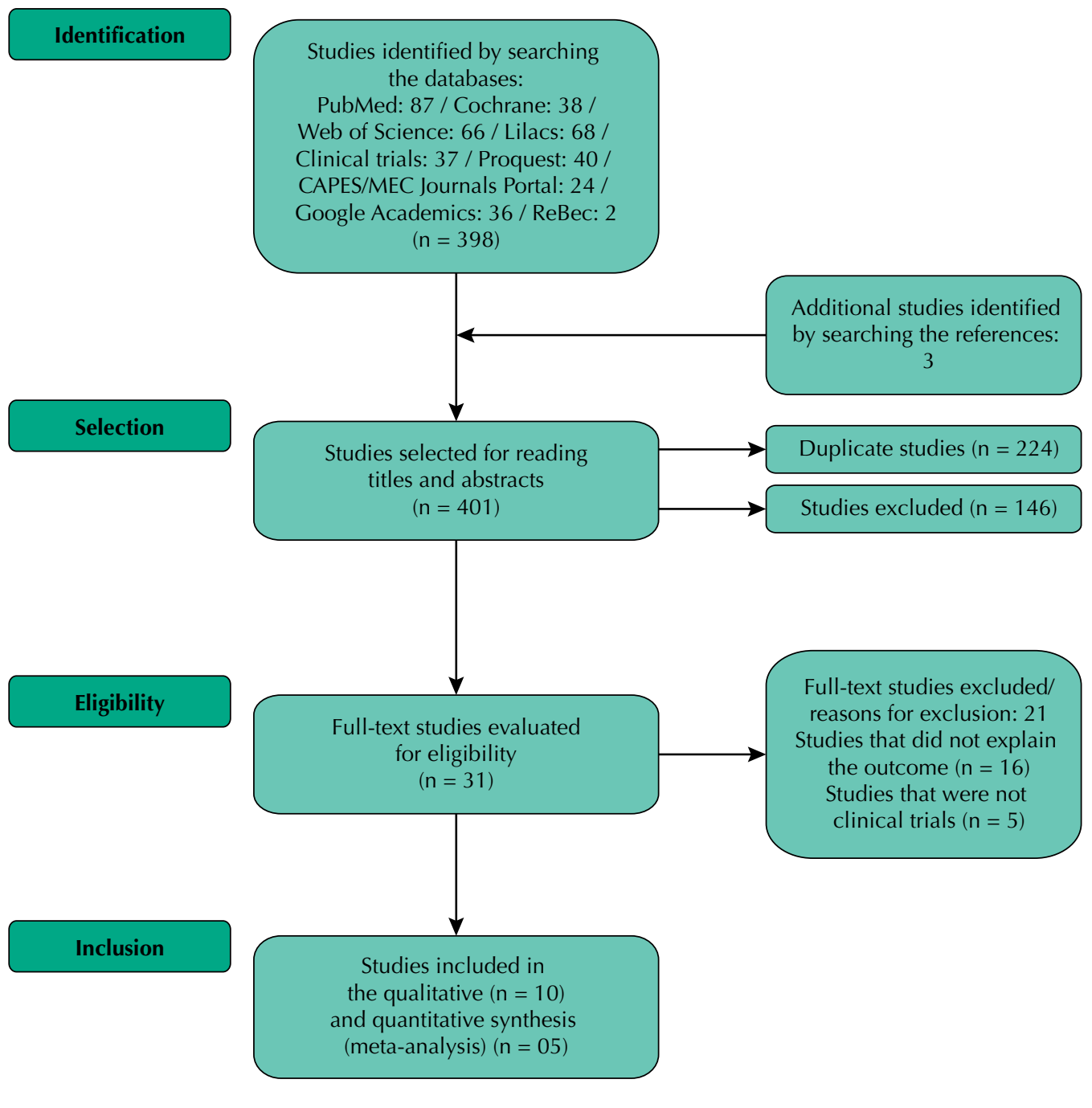

Figure 1. Flowchart of the systematic literature review. 
gentle cleansing technique with a swab inside the mouth, cleaning cheeks, tongue, palate and lips; and another, which administered colostrum by gavage.

One of the studies used milk from the milk bank in the treatment group, when raw colostrum was unavailable ${ }^{22}$. The time of colostrum administration ranged from 48 hours to seven days, with two clinical protocols applying the therapy until the newborns reached full enteral nutrition.

Regarding the control group, six studies used the same administration technique as that of the intervention group, differing only in the use of a placebo (sterile water or saline solution) $)^{6}$. In the other four studies, the control group remained under the routine care at the hospital unit $\mathrm{t}^{7,9,12,21}$.

As for the methodological quality of the studies, assessed by the Cochrane risk-of-bias tool for randomized trials $(\operatorname{RoB} 2)^{18}$, we identified variable quality among all studies: one showed low risk of bias ${ }^{10}$, five were classified with some $\operatorname{concern}^{6,8,9,22,23}$, and the remaining four as a high risk of bias ${ }^{9,11,12,21}$.

All studies reported random allocation of subjects, but two of them did not specify the method used to generate the random sequence ${ }^{7.8}$. Concerning the concealment method, four studies reported blinding the participants ${ }^{6,10,22,23}$ by opaque envelopes and sealed syringes, three studies did not report blinding ${ }^{7,8,11}$, and three reported not being blind ${ }^{9,12,21}$.

Seven studies obtained the data assessed for outcomes from all participants, while three studies assessed only some of the participants ${ }^{6,8,23}$. The analysis considered all the methods used for measuring outcomes as appropriate. Altogether, the studies reported days for complete enteral feeding in 708 VLBW-PTNB. Three of the studies included fewer participants in assessing the time to achieve full enteral nutrition ${ }^{6,8,23}$.

Only three studies reported the faster establishment of full enteral nutrition in the VLBW-PTNB who received oropharyngeal colostrum immunotherapy ${ }^{6,8,9}$. Five studies showed means and standard deviation in days for newborns to achieve full nutrition, and the remaining five showed the results by median and interquartile range. Thus, we selected only five studies for the meta-analysis ${ }^{6,8,9,11,12}$ (Figure 2), as they had the information required to generate a summary measure of mean difference in days to achieve full enteral nutrition.

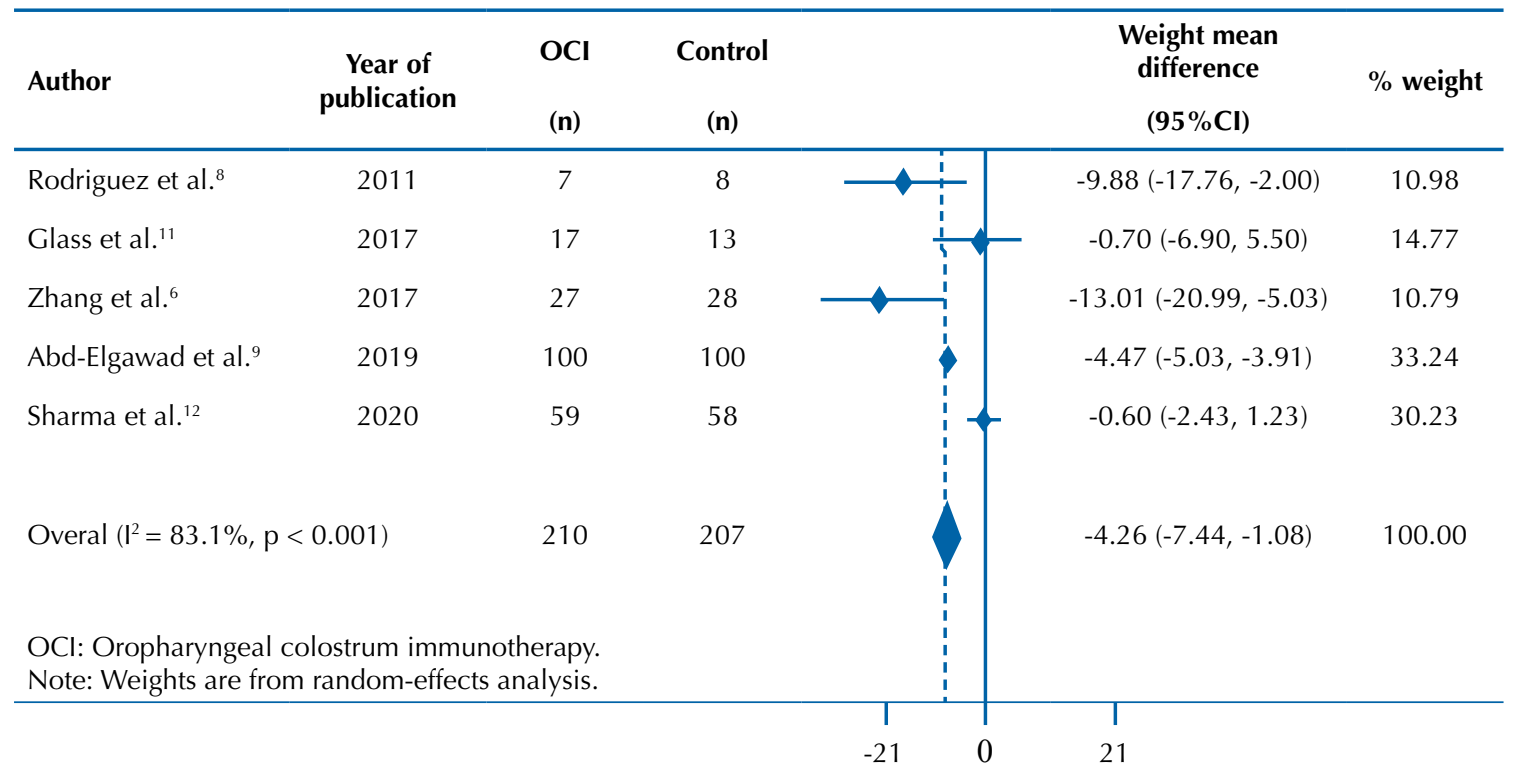

Figure 2. A random-effects meta-analysis of oropharyngeal colostrum immunotherapy over time to achieve full enteral nutrition in very low birth weight preterm infants. 
The five studies included in this meta-analysis reported the oropharyngeal colostrum immunotherapy effect over time to achieve full enteral nutrition in 417 VLBW-PTNB. All five papers estimated the outcome analyzed by mean and standard deviation measures. Three of these studies showed that the colostrum treated group reached full enteral nutrition more quickly $y^{6,8,9}$, whereas the other two found no statistically significant difference when comparing the treated group with the control group ${ }^{11,12}$.

Our meta-analysis of the five studies found a mean difference of -4.26 days, (95\% CI: -7.44; $-1.08 \mathrm{~d}$ ), showing that the use of oropharyngeal colostrum immunotherapy can reduce the time to achieve full nutrition in VLBW-PTNB when compared to those treated with placebo or that received routine care. However, we found a high heterogeneity between these studies $\left(I^{2}=83.1 \%\right)$, and the low number of papers identified for this meta-analysis hindered its adjustment.

\section{DISCUSSION}

The present meta-analysis found that VLBW-PTNB on oropharyngeal colostrum immunotherapy required less time to achieve full enteral nutrition, a result that reinforces the recommendation for using colostrum as an immunological therapy.

Such an intervention is expected to shorten the premature infants' time to achieve full enteral nutrition, since colostrum provides functional nutrients and bioactive components that favor a microenvironment for the defense and maturation of the intestinal mucosa ${ }^{24,25}$ as well as a colonization of the gastrointestinal tract by enteric bacteria with antibacterial functions, immunomodulation, and production of nutritional metabolites, which characterize a healthy microbiome ${ }^{26}$.

Early feeding practices of preterm infants are a potentially modifiable risk factor. Previously, observational studies suggested that conservative diets with slow volume advancement would reduce the risk of necrotizing enterocolitis. However, recent research has shown that slow feeding progress can delay the establishment of full enteral feeding, and may be associated with metabolic and infectious morbidities secondary to prolonged exposure to parenteral nutrition ${ }^{27}$.

Despite its biological plausibility, the quality of the evidence identified in this meta-analysis was low due to the high heterogeneity of the included studies, and the large confidence interval (-7.44 to $-1.08 \mathrm{~d})$. Some methodological characteristics of the individual studies may have contributed to a possible change in the global measure and high heterogeneity, such as small sample size $e^{6,8,10,11,21,23}$, variable clinical protocols, and time defined to reach full enteral nutrition (100 to $150 \mathrm{~mL} \cdot \mathrm{kg}^{-1} \cdot$ day $^{-1}$ ). When evaluating the studied variables, we identified the inclusion of different birth weight values ${ }^{6,9,20}$ and Apgar scores ${ }^{8,11,12}$.

In all studies analyzed, enteral feeding started according to the hospital's protocol or according to individualized treatment for each newborn, with no standardization. Some studies recorded feeding initiation in the first 24 hours after live birth ${ }^{9,23}$ or more than 24 hours $^{7-9}$. These feeding protocols used breast milk, when produced in sufficient quantity ${ }^{6-12,21-23}$, donor milk ${ }^{21}$, or formula ${ }^{9,10,21-23}$. Regarding the number of doses of colostrum administered during treatment, one study ${ }^{8}$ registered the administration of 75 to $85 \%$ of the doses planned for treatment, another ${ }^{6}$ noted that 42 doses were administered during the 7-day therapy, and a third research ${ }^{7}$ reported the administration of 24 doses per newborn.

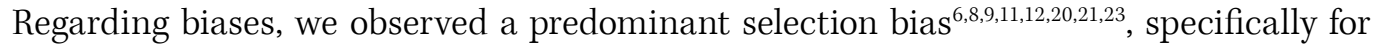
allocation concealment. The analysis found some weaknesses in the text description regarding the information necessary to assess the other bias domains ${ }^{6,8,9,12}$, which can cause essential distortions in the global measure. For example, we identified no use of adjustment for confounder covariables in the primary studies. The present meta-analysis could not assess the publication bias due to the insufficient number of selected studies. 
Even considering the methodological weaknesses of the included studies, they were kept in the analysis given the low number of papers on the topic.

A meta-analysis on the use of this procedure in preventing morbimortality in premature infants, found an association between the use of oropharyngeal colostrum immunotherapy and the rapid achievement of full enteral nutrition. It found very low quality of evidence due to imprecision, high risk of bias, and moderate heterogeneity of the included studies ${ }^{13}$. Two other meta-analysis that studied the effect of this therapy on necrotizing enterocolitis ${ }^{15}$ and prematurity ${ }^{14}$, found no significant results for this association.

Importantly, these previous meta-analyses are grounded on some methodological characteristics recommended by other researchers ${ }^{28,29}$, such as the estimation of the mean and standard deviation by medians and interquartile ranges among the reviewed studies ${ }^{13-15}$.

These methods are questionable, since by assuming that the mean can be estimated from the median, without incorporating the influence of the sample size, this ignores data distribution regarding the principle of normality. It is not reasonable, for example by the method used by Hozo et al. $2005^{29}$, to consider the equivalence between mean and median values for data that present asymmetry in their distribution ${ }^{30}$. Therefore, we understand that the previous meta-analyses on the topic in question present methodological weaknesses ${ }^{31}$.

The present meta-analysis differs from those mentioned as it included only randomized clinical trials with results related to means and standard deviation, without estimating the measures presented in the individual studies. Ours is the second study to have judiciously evaluated the methodological quality of studies using the Rob2 tool ${ }^{18}$, and the first to have investigated exclusively the time to achieve full enteral nutrition in very low birth weight premature newborns, giving visibility to a clinical outcome relevant to their growth and development.

\section{CONCLUSIONS}

Our findings show that the use of oropharyngeal colostrum immunotherapy can reduce the time to achieve full enteral nutrition in VLBW-PTNB when compared to those treated with placebo or routine care. Achieving full enteral nutrition more quickly and without undesirable effects is essential to provide good growth and development for premature infants.

For a better quality of scientific evidence, further studies with standardized colostrum oropharyngeal therapy protocols that explore the time of onset, the dose to be administered, and the frequency and duration of treatment are needed.

Finally, it is important to highlight the importance of colostrum immunotherapy and early and adequate nutrition for these newborns' health in preventing possible unfavorable clinical outcomes, achieving survival with quality of life, and avoiding sequelae in the medium and long term.

\section{REFERENCES}

1. Ziegler EE. Meeting the nutritional needs of the low-birth-weight infant. Ann Nutr Metab. 2011;58 Suppl 1:8-18. https://doi.org/10.1159/000323381

2. Oliveira AG, Siqueira PP, Abreu LC. Cuidados nutricionais no recém-nascido de muito baixo peso. Rev Bras Crescimento Desenvolv Hum. 2008;18(2):148-54. https://doi.org/10.7322/jhgd.19876

3. Garofalo NA, Caplan MS. Oropharyngeal mother's milk: state of the science and influence on necrotizing enterocolitis. Clin Perinatol. 2019;46(1):77-88. https://doi.org/10.1016/j.clp.2018.09.005 
4. Rodriguez NA, Caplan MS. Oropharyngeal administration of mother's milk to prevent necrotizing enterocolitis in extremely low-birth-weight infants: theoretical perspectives. J Perinat Neonatal Nurs. 2015;29(1):81-90. https://doi.org/10.1097/JPN.0000000000000087

5. Margotto PR. Assitência ao recém-nascido de risco. 3. ed. Brasília, DF: Escola Superior de Ciências da Saúde; 2013.

6. Zhang Y, Ji F, Hu X, Cao Y, Latour JM. Oropharyngeal colostrum administration in very low birth weight infants: a randomized controlled trial. Pediatr Crit Care Med. 2017;18(9):869-75. https://doi.org/10.1097/PCC.0000000000001221

7. Sohn K, Kalanetra KM, Mills DA, Underwood MA. Buccal administration of human colostrum: impact on the oral microbiota of premature infants. J Perinatol. 2016;36(2):106-11. https://doi.org/10.1038/jp.2015.157

8. Rodriguez NA, Groer MW, Zeller JM, Engstron JL, Fogg L, Du H, et al. A randomized controlled trial of the oropharyngeal administration of mother's colostrum to extremely low birth weight infants in the first days of life. Neonatal Intens Care. 2011;24(4):31-5.

9. Abd-Elgawad M, Eldegla H, Khashaba M, Nasef N. Oropharyngeal administration of mother's milk prior to gavage feeding in preterm infants: a pilot randomized control trial. JPEN J Parenter Enteral Nutr. 2020;44(1):92-104. https://doi.org/10.1002/jpen.1601

10. Lee J, Kim HS, Jung YH, Choi KY, Shin SH, Kim EK, Choi JH. Oropharyngeal colostrum administration in extremely premature infants: an RCT. Pediatrics. 2015;135(2):e357-66. https://doi.org/10.1542/peds.2014-2004

11. Glass KM, Greecher CP, Doheny KK. Oropharyngeal administration of colostrum increases salivary secretory IgA levels in very low-birth-weight infants. Am J Perinatol. 2017;34(14):1389-95. https://doi.org/10.1055/s-0037-1603655

12. Sharma D, Kaur A, Farahbakhsh N, Agarwal S. Role of oropharyngeal administration of colostrum in very-low-birth-weight infants for reducing necrotizing enterocolitis: a randomized controlled trial. Am J Perinatol. 2020;37(7):716-21. https://doi.org/10.1055/s-0039-1688817

13. Nasuf AWA, Ojha S, Dorling J. Oropharyngeal colostrum in preventing mortality and morbidity in preterm infants. Cochrane Database Syst Rev. 2018;9(9):CD011921. https://doi.org/10.1002/14651858.CD011921.pub2

14. Panchal H, Athalye-Jape G, Patole S. Oropharyngeal colostrum for preterm infants: a systematic review and meta-analysis. Adv Nutr. 2019;10(6):1152-62. https://doi.org/10.1093/advances/nmz033

15. Garg BD, Balasubramanian H, Kabra NS, Bansal A. Effect of oropharyngeal colostrum therapy in the prevention of necrotising enterocolitis among very low birthweight neonates: a meta-analysis of randomised controlled trials. J Hum Nutr Diet. 2018;31(5):612-24. https://doi.org/10.1111/jhn.12585

16. Tang R, Yao X, Shi L. The effects of colostrum on gastrointestinal function and related diseases in premature infants: a comprehensive meta-analysis of randomized controlled trials. Yangtze Med. 2018;2(4):271-80. https://doi.org/10.4236/ym.2018.24029

17. Tao J, Mao J, Yang J, Su Y. Effects of oropharyngeal administration of colostrum on the incidence of necrotizing enterocolitis, late-onset sepsis, and death in preterm infants: a meta-analysis of RCTs. Eur J Clin Nutr. 2020;74:1122-31. https://doi.org/10.1038/s41430-019-0552-4

18. Sterne JAC, Savovic J, Page MJ, Elbers RG, Blencowe NS, Boultron I, et al. RoB 2: a revised tool for assessing risk of bias in randomised trials. BMJ. 2019;366:I4898. https://doi.org/10.1136/bmj.I4898

19. Turner RM, Davey J, Clarke MJ, Thompson SG, Higgins JP. Predicting the extent of heterogeneity in meta-analysis, using empirical data from the Cochrane Database of Systematic Reviews. Int J Epidemiol. 2012;41(3):818-27. https://doi.org/10.1093/ije/dys041

20. Borenstein M, Hedges LV, Higgins JPT, Rothstein HR. Introduction to meta-analysis. Hoboken, NJ: John Wiley \& Sons; 2009.

21. Romano-Keeler J, Azcarate-Peril MA, Weitkamp JH, Slaughter JC, McDonald WH, Meng S, et al. Oral colostrum priming shortens hospitalization without changing the immunomicrobial milieu. J Perinatol. 2017;37(1):36-41. https://doi.org/10.1038/jp.2016.161

22. Ferreira DMLM, Oliveira AMM, Leves DV, Bem EB, Fatureto GG, Navarro NF, et al. Randomized controlled trial of oropharyngeal colostrum administration in very-low-birth-weight preterm infants. J Pediatr Gastroenterol Nutr. 2019;69(1):126-30. httpw://doi.org/10.1097/MPG.0000000000002356 
23. Easo S, responsible, et al. Effectiveness of mother's own colostrum and breast milk as oral immunotherapy and on the feeding behaviors and clinical outcome among preterm infants: a randomized control trial. 2018 [cited 2021 jul 02]. ClinicalTrials.gov Identifier: NCT03633500. Available from: https://clinicaltrials.gov/ct2/show/NCT03633500

24. Jacobi SK, Odle J. Nutritional factors in fluencing intestinal health of the neonate. Adv Nutr. 2012;3(5):687-96. https://doi.org/10.3945/an.112.002683

25. Cacho NT, Lawrence RM. Innate Immunity and breast milk. Front Immunol. 2017;8:584. https://doi.org/10.3389/fimmu.2017.00584

26. Cong $X$, Judge $M, X u W$, Diallo A, Janton $S$, Brownell EA, et al. Influence of infant feeding type on gut microbiome development in hospitalized preterm infants. Nurs Res. 2017;66(2):123-33. https://doi.org/10.1097/NNR.0000000000000208

27. Oddie SJ, Young L, McGuire W. Slow advancement of enteral feed volumes to prevent necrotising enterocolitis in very low birth weight infants. Cochrane Database Syst Rev. 2017;8(8): CD001241. https://doi.org/10.1002/14651858.CD001241.pub7

28. Higgins J, Green S, editors. Cochrane handbook for systematic reviews of interventions: Cochrane book series. Chichester (UK): John Wiley \& Sons; 2008 [cited 2020 jul 01]. Front matter; p. i-xxi. Available from: https://onlinelibrary.wiley.com/doi/book/10.1002/9780470712184

29. Hozo SP, Djulbegovic B, Hozo I. Estimating the mean and variance from the median, range, and the size of a sample. BMC Med Res Methodol. 2005;5:13. https://doi.org/10.1186/1471-2288-5-13

30. Wan X, Wang W, Liu J, Tong T. Estimating the sample mean and standard deviation from the sample size, median, range and/or interquartile range. BMC Med Res Methodol. 2014;14:135 . https://doi.org/10.1186/1471-2288-14-135

31. Luo D, Wan X, Liu J, Tong T. Optimally estimating the sample mean from the sample size, median, mid-range, and/or mid-quartile range. Stat Methods Med Res. 2018;27(6):1785-805. https://doi.org/10.1177/0962280216669183

Acknowledgments: To Shiney Easo and collaborators for providing more information about their study and clearly explaining the methods and the results.

Funding: The project had the financial support of the Foundation for Research Support of the State of Bahia (FAPESB), through Public Notice 003/2017 - Research Program for the SUS: Shared Management in Health PPSUS / BA - FAPESB / SESAB / CNPQ / MS (concession No. 4996/2017 [to VIEIRA, GO]), for the acquisition of permanent and consumable materials in the implementation of the protocol, which enabled data collection.

Authors' Contribution: Contribute substantially to the design and planning of the study: MSXR. Collect the data: MSXR, CCM, EFF. Analyze and interpret the data: MSXR, CCM, EFF, GOV, ISGF, ACMGF, MGP, SSC. Prepare or revise the manuscript: MSXR, CCM, GOV, ISGF, SSC. Approve the final version to be published: MSXR, CCM, EFF, GOV, ISGF, ACMGF, MGP, SSC. Assume public responsibility for the content of the article: MSXR, CCM, EFF, GOV, ISGF, ACMGF, MGP, SSC.

Conflict of Interests: The authors declare no conflict of interest. 